response to Merskey's authoritative paper (Journal, March 1992, 160, 327-340), testifies to the anger which sceptical reactions to MPD can provoke. This is not good science. The issue of the validity of MPD is not going to be settled by such affect-laden exchanges, nor by unverified assertions about the number of psychopathologists who believe this phenomenon is a discrete, naturally occurring, clinical entity. Fahy suggests that Merskey sought publication in a British journal because most North American psychopathologists do not share his scepticism. However, Paul Chodoff, a North American psychiatrist, equally pre-eminent and respected by British psychopathologists such as Merskey, has written in the American Journal of Psychiatry (1987):

"I have been in the practice of clinical psychiatry for the past 40 years.... During this extended period, my experience with multiple personality disorder has consisted of one very doubtful case. Interested by the spate of current reports, I have conducted a very informal poll of my colleagues. Uniformly, they report seeing no instances, or no more than one or two, in their careers up to now. ... I cannot accept that my colleagues and I have been so singularly lacking in diagnostic acumen as to miss recognising an entity now being reported in the hundreds, even thousands. ... Iatrogenic influences operating on suggestible patients in the interests of secondary gain (for psychiatrists as well as patients) cannot be excluded as a possible reason for this disorder".

My own more extensive poll, conducted through the correspondence columns of the Bulletins of the Royal College of Psychiatrists and the British Psychological Society in 1988, produced not a single unequivocal case of MPD.

Lal Fernando, a psychiatrist at the Metropolitan General Hospital, Ontario, has written:

"... according to [Ross] we can deduce that $5 \%$ of all psychiatric admissions in Britain or South Africa will carry DSM-III-R diagnoses. ... Considering the fact that the majority of psychiatrists have never seen or diagnosed a case of MPD on both sides of the Atlantic, I find these figures and predictions incredible".

Thigpen himself (1984) reports seeing no further cases of MPD in the 30 years since his seminal treatment of Eve.

Although MPD does seem a curiously North American phenomenon, the very favourable review of my book Multiple Personality: An Exercise in Deception in the prestigious American journal Contemporary Psychology (1991, 36, 624-625) further testifies to more sympathy for the sceptical position than Fahy cares to admit. The same can be said about the October 1992 workshop organised for the Hospital and Community Psychiatry Institute in
Toronto by Dr Richard Warner, Medical Director of the Mental Health Center of Boulder County, Colorado. The workshop was on the "Overdiagnosis and overtreatment of personality disorders" and Dr Warner is in the process of editing a forthcoming book on the iatrogenesis of a variety of disorders in suggestible individuals.

It simply will not do for believers to accuse sceptics of inexperience or clinical shortcomings not only because this is unfortunately ad hominem rather than ad rem, but also because so many witnesses frankly admit their own lack of experience prior to their first diagnosis of MPD.

In order to persuade the sceptic, believers in MPD frequently resort to reporting the burgeoning numbers of diagnoses. Despite its superficial validity, this position is comparable with arguments for the existence of unidentified flying objects (UFOs) which rest on an increase in their alleged sightings.

\footnotetext{
CHODOFF, P. (1987) Multiple personality disorder. American Journal of Psychiatry, 144, 124.

FERNANDO, L. (1990) Multiple personality disorder. British Journal of Psychiatry, 157, 150.

THIGPEN, C. N. (1984) On the incidence of multiple personality: a brief communication. International Journal of Clinical Experimental Hypnosis, 32, 63-66.
}

Middlesex University

RAY ALDRIDGE-MORRIS

Queensway

Enfield

Middlesex EN3 4SF

\section{HIV infection, serotonin, and sexual dysfunction}

SIR: I read with interest the article by Catalan et al (Journal, December 1992, 161, 774-778). I would like to comment on the development of sexual dysfunction during the human immunodeficiency virus (HIV) infection.

Serotonin has been implicated in the control of sexual behaviour, and the administration of the serotonin precursor 5-hydroxytryptophan, in combination with a peripheral decarboxylase inhibitor, has a facilitatory effect on the sexual behaviour of male mice (Svensson et al, 1987).

HIV infection significantly reduces serum tryptophan (Werner et al, 1988; Larsson et al, 1989) and blood serotonin (Larsson et al, 1989). This dramatic degradation of the essential amino acid tryptophan results in decreased serotonin biosynthesis and neurotransmission in the brain (for review see Green \& Costain, 1981). These changes are thought to be due to the induction of the enzymes indoleamine 2,3-dioxygenase and tryptophan 2,3-dioxygenase by 
cytokines as a result of HIV infection (Werner $e t$ al, 1988, 1989).

Reduced serotonergic neurotransmission by HIV infection may therefore contribute to explain the development of sexual dysfunction during the HIV infection.

Green, A. R. \& Costain, D. W. (1981) Pharmacology and Biochemistry of Psychiatric Disorders. Chichester: John Wiley.

LARSSON, M., HAGBERG, L., NorkRANS, G., et al (1989) Indoleamine deficiency in blood and cerebrospinal fluid from patients with human immunodeficiency virus infection. Journal of Neuroscience Research, 23, 441-446.

Svensson, K., LARSSON, K., AhLEnIUS, S., et al (1987) Evidence for a facilitatory role of central 5-HT in male mouse sexual behaviour. In Brain 5-HTIA Receptors: Behavioural and Neurochemical Pharmacology (eds C. T. Dourish, S. Ahlenius \& P. H. Hutson), pp. 199-210. Chichester: Ellis Horwood.

Werner, E. R., FuChs, D., HAusen, A., et al (1988) Tryptophan degradation in patients infected by human immunodeficiency virus. Biological Chemistry Hoppe-Seyler, 369, 337-340.

-, Werner-Felmayer, G., Fuchs, D., et al (1989) Paralle induction of tetrahydrobiopterin biosynthesis and indoleamine 2,3-dioxygenase activity in human cells and cell lines by interferon- $\gamma$. Biochemical Journal, 262, 861-866.

Pharmaceutical Sciences Institute

SERDAR M. DURSUN Aston University

Birmingham B4 7ET

\section{Hysteria in childhood}

SIR: Garralda (Journal, December 1992, 161, 759-773) points to the paucity of studies on hysterical conversion symptoms in childhood in the psychiatric literature. I would like to offer some explanations for this from my own recent experience in carrying out a pilot study on this topic.

A pilot study was conducted on all children admitted to a district general hospital between December 1989 and May 1991, under all departments of the hospital. It was hoped to identify children with functional illness from the diagnoses in the ward admission books. Case notes of all such children were examined.

Of the 8517 children admitted to the hospital, 191 might have had functional illness: 160 of these were suffering from abdominal pain that did not result in surgery; the remaining 31 suffered from a variety of complaints of pain or loss of function. Four of these children fulfilled diagnostic criteria for hysterical neurosis, conversion type: one was a 16-year-old girl with a history of sexual abuse; one was a 7-year-old girl for whom no definite diagnosis was made but an investigation into sexual abuse had been undertaken some years previously; the remaining two were Asian boys aged 13 and 11. One of the boys had been involved in a road traffic accident and his father was pursuing compensation, the other was an obese, aggressive, school refuser whose family background was unknown. Over a similar time period, two local child psychiatry in-patient units each admitted one patient with hysterical neurosis, conversion type: both were 16-year-old girls with histories of sexual abuse.

This study highlights the difficulties in identifying cases of hysterical conversion. The admission rate was just $0.4 \%$ for paediatric units and $1.4 \%$ for in-patient child psychiatry units.

In addition, the findings are suggestive of the need to exclude sexual abuse in all children presenting with hysterical neurosis (conversion type), especially if it is severe enough to warrant either paediatric admission or referral to child psychiatry.

\section{J. FEEHAN}

\author{
Children's Services Division \\ Heathlands (Charles Burns Clinic) \\ Queensbridge Road, Moseley \\ Birmingham B13 8QD
}

\section{Hysterical conversion and developmental psychiatry}

SIR: The comprehensive papers by Dr Mace (Journal, September 1992, 161, 369-377 and 378-389) on hysterical conversion do not mention its frequency in childhood. Mace's remarks on the nosological status of conversion would be reinforced if childhood, and even infancy, were taken into account. The use of hysteria as a clinical category has decreased, largely due to the confusion and obscurity of the concept. For instance, conversion disorder and hysteria have both disappeared from the chapter on disorders of infancy and childhood in the DSM-III-R manual (American Psychiatric Association, 1987). However, conversion is known to be frequent at certain phases of childhood, particularly when physiological changes shake up the mental representation of the body, both during the latency period and during adolescence. Conversion disorder in infancy can also be linked with many different types of psychopathology, ranging from a single episode in an almost normally developing child, to borderline or frankly psychotic disorders.

The role of depression in the genesis of a conversion episode is stressed by many. Such cases of early conversion disorder were described as early as 1897 by Terrien, and by some others since, including Anna Freud (1926). Goodyer (1981) proposes to label as conversion anything that looks like it regardless of age. It seems that conversion can be seen as a potentiality that tends to disappear with age, but can be 